1977

\title{
Survey of Criminal Procedure - Alternative Dispositions of Defendants
}

Charles Shafer

University of Baltimore School of Law, cshafer@ubalt.edu

Follow this and additional works at: http://scholarworks.law.ubalt.edu/all_fac

Part of the Criminal Law Commons, Criminal Procedure Commons, and the Supreme Court of the United States Commons

\section{Recommended Citation}

Survey of Criminal Procedure — Alternative Dispositions of Defendants, 30 Rutgers L. Rev. 592 (1976-1977)

This Article is brought to you for free and open access by the Faculty Scholarship at ScholarWorks@University of Baltimore School of Law. It has been accepted for inclusion in All Faculty Scholarship by an authorized administrator of ScholarWorks@University of Baltimore School of Law. For more information, please contact snolan@ubalt.edu. 


\section{Survey of Criminal Procedure- Alternative Dispositions of Defendants}

The criminal justice system provides various alternatives for the disposition of criminal defendants. Three of these alternatives, pretrial intervention, drug treatment, and probation, were dealt with in recent New Jersey Supreme Court decisions. The court examined the substantive criteria and procedures used in assigning each disposition and focused primarily on the desire to provide rehabilitative opportunities for each defendant. This note will examine those decisions and the implications of the court's concentration on the goal of rehabilitation.

\section{Pretrial Intervention}

In State v. Leonardis" and in subsequently issued "Guidelines for Operation of Pretrial Intervention in New Jersey," 2 the court established new criteria and procedures governing admission to Pretrial Intervention (PTI) Programs. These programs provide defendants the opportunity to have complaints or indictments dismissed with the approval of the program director and the prosecutor upon successful participation in a program of treatment and counseling. ${ }^{3}$

In Leonardis, the court invalidated restrictive Bergen County PTI admissions criteria and held that PTI programs may no longer use the nature of the crime with which the defendant is charged as the sole basis for rejection. ${ }^{4}$ Under the Bergen County criteria, defen-

1. 71 N.J. 85, 363 A.2d 321 (1976), Motion for Clarification and Rehearing Granted, No. M-1234 (Sept. 8, 1976).

2. 99 N.J.L.J. 865 (1976) [hereinafter cited as Guidelines].

3. N.J. Cr. R. 3:28 authorizes the county assignment judge (or a judge he appoints) to suspend proceedings against any defendant on recommendation of the program director with the consent of the prosecutor and the defendant. The program lasts three months, after which the charges against the defendant are dismissed, the program is extended three months, or the defendant is returned to the ordinary course of prosecution. Participation is limited to two three-month periods, except in cases of drug dependency.

The supreme court has approved PTI programs in 17 counties. See J. Paul, Pretrial Intervention: A Report On A Workshop Sponsored by the N.J. Bar Institute \& Law Center, Feb., 1976, 99 N.J.L.J. 865, 875 (1976); Notice to the Bar Re PTI in Ocean County, 100 N.J.L.J. 121 (1977); Notice Re PTI in Burlington County, id.; Notice to the Bar Re PTI in Hunterdon County, 100 N.J.L.J. 91 (1977); Notice to the Bar Re PTI in Somerset County, 100 N.J.L.J. 78 (1977); Notice to the Bar Re PTI in Salem County, 100 N.J.L.J. 66 (1977). For a description of the New Jersey PTI Program, see 28 Rutgens L. Rev. 1203 (1975). The court has also provided an extensive discussion of the legal background of PTI. 71 N.J. at 92-107, 363 A.2d at 324-32.

4. 71 N.J. at $112,363 \mathrm{~A} .2 \mathrm{~d}$ at 335 . Leonardis combined the appeals of three defendants, two from Bergen County and one from Hudson County. The issues raised by the appeal of the Hudson County defendant are discussed at text accompanying notes $26-33$ infra. 
dants charged with certain offenses were ordinarily denied entrance into the program. ${ }^{5}$ Two of the defendants in Leonardis, one charged with possession with intent to distribute marijuana and the other indicted for conspiracy to distribute marijuana, had been summarily excluded because "sale of a controlled dangerous substance" was listed as one of those offenses. ${ }^{6}$

The court determined that since the main purpose of PTI programs is rehabilitation, admission should be based not on the offense but on the offender's capacity for rehabilitation. Important considerations ignored by the Bergen County officials were "the defendant's willingness to avoid conviction and its attendant stigma, the motivation behind the commission of the crime, the age and past criminal record of the defendant and his current rehabilitation efforts." 7 In striking down the Bergen County admissions standards, the court expressed concern for the possibility that arbitrary denial of the rehabilitative benefits of PTI may be a denial of equal protection. ${ }^{8}$ Noting, however, that the United States Supreme Court would prob-

5. The following offenses were expressly excluded under the Bergen County criteria:

1. Heinous Offenses: Atrocious Assault and Battery where the victim is seriously injured; Homicide; Mayhem; Forcible Rape; Assault and Battery on a Police Officer involving injury; Armed Robbery where the victim is injured; Sale of a Controlled Dangerous Substance. . . .

2. Offenses Related to Psychological Disorder: . . . . Arson, aberrant sexual behavior including Incest, Sodomy, Indecent Exposure, when associated with psychological defect or the use of force to attempt any sexual act. . . .

3. Victimless Crimes ... . : Prostitution and Gambling. Bergen County Pre-Trial Intervention Project (unpaginated) (undated).

The Hudson County PTI program excluded offenders charged with "heinous offenses," including crimes of extreme violence when associated with serious injury and sale or dispensing of significant amounts of controlled dangerous substances or other drugs, especially where not associated with the applicant's addiction. Zaloom, Pretrial Intervention Under New Jersey Court Rule 3:28, Proposed Guidelines for Operation, 2 Chiminal Justice Quarterly 178, 185 (1974).

6. The supreme court opinion states only that defendant Leonardis was charged with possession of marijuana. The actual complaint filed against Leonardis charged him with "possession with intent to distribute." Brief for Defendant-Appellant in Support of Motion for Leave to Appeal at 2, State v. Leonardis, 71 N.J. 85, 363 A.2d 321 (1976). Apparently there was proof that Leonardis intended to sell the marijuana, because the defendant's statement of facts acknowledged that the offense "involved the sale of marijuana." Id. There is no separate New Jersey statute covering "sale" of controlled dangerous substances. Rather, sales are subsumed under "distribution." See N.J. Stat. AnN. \$ 24:21-19 (Supp. 1976).

7. 71 N.J. at 112,363 A.2d at 335 .

The defendants contended that the program officials were not fairly applying their own criteria because use of the phrase "ordinarily excluded" implied that even those charged with "heinous offenses" should have an opportunity to present arguments for their admission. Id. at 110, 363 A.2d at 334. The court, however, was careful to point out that it was not merely examining the criteria "as applied." Rather, the court found that the criteria themselves unduly emphasized the nature of the offense. Id. at $111-12,363 \mathrm{A.2 \textrm {d }}$ at 335 .

8. Id. at $112-13,363 \mathrm{~A} .2 \mathrm{~d}$ at $335-36$. 
ably not find that equal protection gives rise to a right to rehabilitation, ${ }^{9}$ the New Jersey court characterized its decision as an interpretation of court rules. ${ }^{10}$ The court also expressed concern for the equal protection implications of the county-by-county variations in the availability of PTI throughout the state and urged adoption of a uniform statewide program based on the principles espoused in Leonardis. ${ }^{11}$

Two months after the Leonardis opinion the supreme court adopted PTI Guidelines as the foundation for such a statewide program. The Guidelines, which apply to all state PTI programs, set forth the goals of PTI, criteria to be employed in making admissions decisions, and procedures for defendants to contest unfavorable decisions on the part of prosecutors or program officials. The spirit of Leonardis is maintained by requiring that admission decisions be based on the defendant's "amenability to correction [and] responsiveness to rehabilitation" as well as on the nature of the offense. ${ }^{12}$ The Guidelines require, therefore, that programs consider applications from "[a]ny defendant accused of crime," and accept any defendant who "demonstrates sufficient effort to effect necessary behavioral change and show [s] that future criminal behavior will not occur." ${ }^{13}$

The Guidelines, however, retreat somewhat from the position that it is improper to predicate admissions on the nature of the defendant's

9. See Marshall v. United States, 414 U.S. 417 (1974).

10. 71 N.J. at $108-09,363$ A.2d at 333-34.

11. Id. at $120-21,363 \mathrm{~A} .2 \mathrm{~d}$ at 340 . This reasoning was adopted in State v. Kowitski, 145 N.J. Super. 237, 367 A.2d 459 (Law Div. 1976) (defendant denied equal protection of law because county in which crime was committed had no PTI program while "right" of access to PTI was granted defendants in other counties; rendered moot by adoption of Somerset County PTI program).

12. Guidelines, supra note 2 , at 865 .

13. Id. at 874 (Guideline 2). The court's action reflects a national trend toward expanding the scope of diversionary programs to include persons charged with crimes once considered quite serious. Barriers to drug offenders in particular are being abolished. R. Nimmer, Diversion: The Search for Alternative Forms of Phosecution 17, 49-50, 57-58 (1974). Both the New Jersey Supreme Court and the legislature have previously endorsed a policy of avoiding harsh penalties for minor drug offenders. $C f$. State v. Ward, 57 N.J. 75, 270 A.2d 1 (1970); State v. Staten, 62 N.J. 435, 303 A.2d 65 (1973) (per curiam). But cf. State v. Knight, 72 N.J. 193, 369 A.2d 913 (1976) (refusal to review trial court's choice of prison term instead of Youth Correctional Institutional Complex commitment for twenty-two-year-old heroin addict never previously incarcerated). The expansion of PTI programs coincides with a growing dissatisfaction with the results of prolonged incarceration and a desire, therefore, to impose the shortest possible periods of confinement. See, e.g., Advisony Comm. on Sentencing and Review, A.B.A. Project on Minimum Standards, Sentencing Alternatives and Procedures 61-63 (Approved Draft 1968); Model Penal Code $\$ 7.01$ (Proposed Official Draft 1962); Task Force on Administration of Justice, President's Commission on Law Enforcement and administration of Justice, Task force Report: The Courts 15 (1967). 
offense. ${ }^{14}$ For example, the Guidelines emphasize PTI's concern with the "less serious" offenses by stating that one purpose of PTI is to divert consideration of those offenses from the courts in order to "focus expenditure of criminal justice resources on matters involving serious criminal and severe correctional problems." 15 Furthermore, although defendants accused of any crime are eligible for admission, Guideline 3 (i) requires that programs should ordinarily reject defendants charged with crimes which are:

“(1) part of organized criminal activity; or (2) part of a continuing criminal business or enterprise; or (3) deliberately committed with violence or threat of violence against another person; or (4) a breach of the public trust where admission to a PTI program would deprecate the seriousness of defendant's crime . . . "16

The Guidelines also provide that several other groups of offenders should ordinarily be rejected, i.e., defendants who have previously been convicted of crimes of a "serious nature" or who have previously been enrolled in PTI or similar programs. ${ }^{17}$

Therefore, while the court recognizes that it may be unwise to admit to PTI those who have committed serious crimes, Guideline 3 (i) redefines the term "serious crime" for purposes of PTI. Guideline 3 (i) presents a potential problem in that the standards used in the redefinition do not appear to further the court's avowed goals of uniformity and predictability of decisions, ${ }^{18}$ simply because they are not the kind of standards that can ever be reduced to uniformity and predictability. In contrast to the Bergen County criteria which listed specific crimes which ordinarily precluded admission, ${ }^{19}$ Guideline 3(i) dictates that defendants charged with crimes in four broad categories be excluded. ${ }^{20}$ Those categories require subjective determinations based on more factors than the alleged criminal acts. The court does not supply standards for deciding whether an act is part of organized crime, ${ }^{21}$ a continuing criminal enterprise, or a breach of public trust. Similarly, Guideline 3(e) mandates that those who

14. The "retreat" from Leonardis is also made evident in the heavy burden placed on those who are denied admission to PTI to challenge that determination. See text accompanying note 29 infra.

15. Guidelines, supra note 2, at 865 (Guideline 1(D)) (emphasis added).

16. Guidelines, supra note 2 , at 874 .

17. Id. (Guidelines 3(E), 3(G)).

18. See State v. Leonardis, 71 N.J. at 98,363 A.2d at 328.

19. See note 5 supra.

20. See text accompanying note 16 supra.

21. For examples of the difficulty involved in using "organized crime" as a legal standard, see Catalano v. United States, 383 F. Supp. 346, 349-50 (D. Conn. 1974). For an example of the scope of activity that could be subsumed under "organized crime," see "Hustler" Conviction Is Pondered in Ohio, N.Y. Times, Feb. 10, 1977, at 21, col. 6 (collaboration to promote obscene magazine is within Ohio's organized crime statute). 
have previously committed "serious" crimes should ordinarily be excluded without further explanation as to which crimes are "serious." 22

Moreover, the court's general mandate that decisions be based on the defendant's "amenability to correction [and] responsiveness to rehabilitation" provides no explanation of the bases on which such determinations are to be made. It is doubtful that anyone can accurately predict who will successfully respond to a PTI program. ${ }^{23}$ Nevertheless, the court assumes that program officials can identify such individuals. ${ }^{24}$

The court's effort to open the program to more defendants and the concomitant replacement of definite criteria with vague standards may increase the exercise of individual discretion by program officials without adequate review or guidance. In this respect, therefore, the Guidelines may be counterproductive of the goal of statewide uniformity. ${ }^{2 b}$

In addition to the court's redefinition of substantive PTI admission standards, the court has also changed PTI admissions procedures. In Leonardis, the court affirmed a Hudson County trial judge's order that the prosecutor must provide a written explanation for his refusal to admit a defendant into PTI. ${ }^{26}$ The court viewed this requirement

22. Guidelines, supra note 2 , at 865 .

23. No controlled study of PTI has ever been made in New Jersey. Paul, supra note 3 , at 879 . For an analysis of statistical claims of success of the Manhattan Court Employment Project, which indicates that no conclusion can be drawn as to the effectiveness of that program, see Zimring, Measuring the Impact of Pretrial Diversion from the Criminal Justice System, 41 U. CHI. L. Rev. 224 (1974).

The inability to evaluate offenders on an ad hoc, individualized basis is demonstrated by the United States Board of Parole's decision to abandon the rehabilitative model in determining parole eligibility. Coffee, The Future of Sentencing Reform: Emerging Legal Issues in the Individualization of Justice, 73 MICH. L. REv. $1361,1440-41$ (1975). The date of parole is now determined largely by guidelines which rate inmates on the basis of the seriousness of the offense they have committed and a "salient factor score" which is a function of objective criteria such as prior convictions, age, age at first conviction, education, and proposed living site upon release. 28 C.F.R. $\$ 2.20$ (1976). These factors determine whether or not the prospective parolee is in a class of people likely to commit another crime. One commentator points out that by using such criteria, "the Board has implicitly acknowledged that it is unable to judge or measure rehabilitative progress and so will confine its efforts to seeking to incapacitate offenders." Coffee, supra, at 1441. See also Parole Release Decisions and the Sentencing Process, 84 YaLE L. REv. $810,820-24$ (1975).

24. The court may have been impressed by claims of success of various programs. For example, the Hudson County program cites case histories of "successfully rehabilitated" defendants such as "Sergio Q.," whose offense of atrocious assault and battery was determined to be the result of his unemployment. After being provided with counseling and a job, he did not repeat the offense. Zaloom, supra note 5 , at 187-88. The program, however, does not report the number of such diagnoses which turned out to be wrong. The claims of success of many diversionary programs are based on such impressionistic judgments, rather than on empirical studies. Nimmen, supra note 13 , at 4.

25. 71 N.J. at $120-21,363$ A.2d at 340 .

26. Id. at 119,363 A.2d at 339 . 
as consistent with the national and state trend toward imposing due process requirements on all government decisions which result in a "grievous loss" of liberty or property. Here, the defendant's interest in obtaining the rehabilitative benefits of a PTI program warranted at least a statement of reasons for denial of admission. The court also noted that recorded reasons for exclusion from the program will facilitate judicial review of the prosecutor's actions, further the goals of PTI by providing information on which to evaluate and improve the still experimental programs, and serve the rehabilitative function by causing defendants to feel that they have been dealt with fairly. ${ }^{27}$

The Guidelines further expand the procedural protections afforded the defendant. Each defendant is given the opportunity to present arguments for his acceptance in the program and to contest his exclusion. Under the Guidelines, "[w]hen the application indicates factors which would ordinarily lead to exclusion ... the applicant nevertheless shall have the opportunity to present . . . any facts or materials demonstrating his amenability to the rehabilitative process, showing compelling reasons justifying his admission and establishing that a decision against enrollment would be arbitrary and unreasonable." 28

Following the court's language in Leonardis, the Guidelines require program directors as well as prosecutors to disclose their reasons for granting or denying requests for PTI admissions in writing. Furthermore, the defendants may challenge these decisions before the designated judge. "The challenge is to be based upon alleged arbitrary or capricious action, and the defendant has the burden of showing that the program director or prosecutor abused his discretion in processing the application. ... [T]hereafter, defendant or prosecutor can . . . appeal from the court's decision. . . ."29

The new admission procedures represent a continuation of a trend to increase procedural protections available in New Jersey PTI programs. In 1974, the New Jersey court rules were amended to give the accused an opportunity to be heard, with counsel, on a recommendation that the prosecution proceed after the accused had participated in the program: The defendant was also protected from

27. Id. at $114-19,363 \mathrm{~A} .2 \mathrm{~d}$ at $336-39$. For further discussion of the reasons given in sentencing, see 30 Rutgers L. Rev. 657 (1977).

28. Guidelines, supra note 2 , at 874 (Guideline 2). Prior to promulgation of the Guidelines, a hearing was required only for those enrolled in PTI and returned to the ordinary course of prosecution. No opportunity was provided to challenge the denial of admission to PTI at the outset. N.J. CT. R. 3:28.

29. Guidelines, supra note 2 , at 875 (Guideline 8 ). The jurisdiction of appellate courts to review PTI decisions was challenged by the state. $71 \mathrm{~N}$.J. at 108,363 A.2d at 333. The court conceded that court rules did not provide for such review and based its jurisdiction on its authority to interpret court rules. Id. at 108-09, 363 A.2d at $333-34$. 
the use at trial of program reports as well as statements made during participation in PTI. ${ }^{30}$ This protection was enhanced by the inclusion of all PTI records and reports within the scope of Rule 1:38, which protects the confidentiality of court records. ${ }^{31}$ The rules also require judges to inform defendants of application procedures for PTI programs. ${ }^{32}$

The requirement that the prosecutor provide written, reviewable reasons for any decision concerning PTI admission represents a policy of expanded judicial review of prosecutorial discretion. Traditionally, the courts have been reluctant to interfere in prosecutorial decisions because of the prosecutor's position as a representative of the executive branch historically vested with broad discretionary powers. ${ }^{33}$

30. N.J. CT. R. 3:28, Comment (Pressler ed. 1976).

31. N.J. CT. R. 1:38, Comment (Pressler ed. 1976). This protection is repeated in Guideline 5. The court emphasized that the maintenance of a counselor-patient relationship is more important than the need for disclosure at trial, and that the use of information gathered in a PTI program would be "contrary to basic standards of due process and fundamental fairness." Guidelines, supra note 2 , at 874 .

32. N.J. CT. R. 3:4-2, Comment (Pressler ed. 1976).

33. See In re Ringwood Fact Finding Comm., 65 N.J. 512, 526, 324 A.2d 1, 8 (1974) (Pashman, J., concurring and dissenting in part). See also State v. Conyers, 58 N.J. 123, 147-48, 275 A.2d 721, 733-34 (1971) (trial court should honor prosecutor's request to waive the death penalty although jury verdict called, by implication, for that sentence); Anderson v. Sills, 56 N.J. 210, 225, 265 A.2d 678, 686 (1970) (reversed chancery division's grant of summary judgment for declaratory judgment against Attorney General's memorandum asking local officials for reports on potential civil disorders: "It is a serious matter for the judiciary to interfere with the preventive measures devised by the executive branch . . ."); State v. LeVien, 44 N.J. 323, 326-27, 209 A.2d 97, 99 (1965) (individual who killed fellow mental patients had no right to have criminal proceeding brought against him); State v. Murphy, 36 N.J. 172, 177-78, 175 A.2d 622, 625 (1961) (error for trial court to issue subpoena on its own motion for statement that prosecutor had agreed not to use at trial: "A prosecutor may sensibly decide . . . not to use evidence which would advance the State's case"); State v. Walls, 138 N.J. Super. 445, 449, 351 A.2d 379, 381 (1976) (trial court may not require prosecutor to conduct a lineup).

The federal courts have refused to review prosecutorial decisions unless the prosecutor denies a constitutional right or unconstitutionally discriminates against a defendant. "[T]he conscious exercise of some selectivity in enforcement is not in itself a federal constitutional violation," unless "selection [is] deliberately based upon an unjustifiable standard such as race, religion or other arbitrary classification." Oyler v. Boles, 368 U.S. 448, 456 (1962). See also Newman v. United States, 382 F.2d 479 (D.C. Cir. 1967); United States v. Cox, 342 F.2d 167 (5th Cir.), cert. denied sub nom. Cox v. Hauberg, 381 U.S. 935 (1965).

This approach is illustrated in United States v. Smith, 354 A.2d 510 (D.C. Ct. App. 1976). There the District of Columbia Court of Appeals upheld a prosecutorial policy of denying diversionary program admission to any defendant who litigated any issue in his case. Smith was denied admission because he made a pretrial motion to dismiss, alleging that the penalty he faced violated the eighth amendment. The court held that, since he could have raised the constitutional issue after the prosecutor considered his eligibility for diversion, the prosecutor's policy did not prevent Smith from exercising his eighth amendment rights. The court stated, however, that any prosecutorial policy that had that objective or effect would be invalid. Id. at 514. The same court subsequently upheld a District of Columbia Superior Court order requiring 
There has been, however, some indication in New Jersey of judicial interest in overseeing prosecutorial discretion. In State v. Winne ${ }^{34}$ the supreme court held that a county prosecutor could be found guilty of common law nonfeasance in office without a showing of corruption or willfulness. ${ }^{35}$ The court rejected the argument that removal by impeachment is the "sole remed[y] available to the State for any misconduct of a county prosecutor" ${ }^{86}$ and declared that the prosecutor "must at all times act in good faith and exercise all reasonable and lawful diligence in every phase of his work." ${ }^{87}$ In In re Investigation Regarding Ringwood Fact Finding Committee ${ }^{38}$ the court announced, but did not exercise, its power "within the extraordinarily comprehensive prerogative writ jurisdiction" to review prosecutorial decisions. $^{39}$ In Leonardis the court appears to have taken the first steps toward actually reviewing a prosecutor's discretionary acts.

Nonetheless, the court has not indicated the proper dimensions of prosecutorial discretion with regard to PTI programs. ${ }^{40}$ Realistic stan-

the prosecutor to produce written guidelines relating to the operation of the District's First Offender Treatment Program. The order had issued because the defendant alleged that he was refused admission to the program because of the political nature of his crime. The prosecutor refused to comply with the order and was thus held in "technical" contempt. See In re Cys, 362 A.2d 726 (D.C. Ct. App. 1976).

The National Advisory Commission on Criminal Justice Standards and Goals refers to the "prosecutor's fundamental right to prosecute." Standard 2.2 states that " $[t]$ he decision by the prosecutor not to divert a particular defendant should not be subject to judicial review." National Advisory Commussion on Cruminar. Justice Standards and Goars: Courts Repont 40-41 (1973) [hereinafter cited as Counrs]. The proposed Prosecutorial Discretion Act, a statutory PTI program, would relegate all decisions about diversion to the prosecutor's discretion with no allowance for judicial review. See N.J. Assembly Bill No. 1648 (1976); N.J. Assembly Bill No. 906 (1976).

34. 12 N.J. 152,96 A.2d 63 (1953).

35. The Bergen County prosecutor was indicted for failing to investigate illegal gambling activities of which he was aware. Id. at 162, 96 A.2d at 68 .

36. Id. at $171-72,96 \mathrm{~A} .2 \mathrm{~d}$ at 73 .

37. Id. at 174, $96 \mathrm{~A} .2 \mathrm{~d}$ at 74 .

38. 65 N.J. 512,324 A.2d 1 (1974).

39. Id. at 516-17, 324 A.2d at 3-4. In Ringwood the court reversed an order compelling a prosecutor to present to a grand jury evidence of an election law violation. The court stated that the election law authorized such orders, but found that the prosecutor had not acted arbitrarily. Id. at $516,324 \mathrm{~A} .2 \mathrm{~d}$ at 3 . The court quoted approvingly Kenneth Culp Davis' criticism of judicial reluctance to review prosecutorial discretion and his statement that "courts should continue their gradual movement toward opening the judicial doors to review of prosecutors' discretion." Id. at $516 \mathrm{n} .^{\circ}, 324$ A.2d at $3 \mathrm{n} .^{\circ}$.

40. There has been increasing advocacy of "explicit [prosecutorial] policies for the dismissal or informal disposition of the cases of certain marginal offenders." Pres1dent's Commission on Law Enforcement, The Challenge of Crime in a Free Society 134 (1967) [hereinafter cited as Challenge]; see also Advisony Commrtee on the Prosecution and Defense Functions, A.B.A. Project on Standards for Cruminal Justice, The Prosecution Function and the Defense Function 64-68, 84 (Approved Draft 1971) [hereinafter cited as Prosecumon]; Courrs, supre note 33 , at 39 . 
dards for review are a prerequisite for effective review. ${ }^{41}$ The Leonardis opinion and the Guidelines emphasize decisionmaking based on the personality of the defendant and his susceptibility to rehabilitation. Prosecutors are trained as lawyers, however, not mental health professionals. Even trained professionals are not necessarily able to make reliable judgments similar to those demanded by the court. ${ }^{42}$ If a prosecutor's conclusion that the defendant has low rehabilitative potential will satisfy the court's demand for a statement of reasons, no meaningful judicial review will take place.

Furthermore, neither Leonardis nor the Guidelines gives any guidance as to whether other typical prosecutorial concerns will be considered valid bases upon which to make admissions decisions. Would the court allow a prosecutor to deny entry into PTI to a defendant who could be rehabilitated and whose crimes fell outside the four offense categories ordinarily excluded from admission under Guideline 3(i), but which the prosecutor felt "were the kinds of offenses that should be most vigorously prosecuted in view of the community's law enforcement needs"? ${ }^{43}$ Could the prosecutor consider the deterrent effects of prosecution? ${ }^{44}$ Could the prosecutor choose to divert his "weak" cases and prosecute his "strong" ones? ${ }^{45}$ Would the court permit a prosecutor with limited resources to prosecute only a few offenders selected at random and to divert others charged with the same crime? ${ }^{46}$ Would the court consider it proper for the prosecutor to give any weight to the feelings of the victim? ${ }^{47}$

41. The Leonardis court suggests that there will be judicial review of two aspects of the prosecutor's decision, the judgment of the seriousness of the offense and the conclusion about rehabilitative potential. See 71 N.J. at 122, 363 A.2d at 340. But without more explicit standards, prosecutors may be able to thwart judicial review of PTI admissions decisions through the use of "boilerplate" language, as they now avoid review of decisions not to prosecute by announcing that available evidence is insufficient. See F. Miller, Prosecution: The Decision to Charge a Suspect with a Chime 154-56 (1969).

42. See note 23 and accompanying text stopra.

43. See Challenge, supra note 40, at 133; see generally Nimmer, supra note 13 , at 96 .

44. Although Guidelines $1(\mathrm{a})$ and 1 (b) use the word "deter" in listing the purposes of PTI, it appears that it is used to mean merely "prevent" rather than "prevent through fear," its common meaning.

45. See generally NimMER, supra note 13 , at 13 .

46. "Selective enforcement may also be justified when a striking example or a few examples are sought in order to deter other violators, as part of a bona fide rational pattern of general enforcement, in the expectation that general compliance will follow and that further prosecutions will be unnecessary." People v. Utica Daw's Drug Co., 16 App. Div. 12, 21, 225 N.Y.S.2d 128, 136 (1962).

47.

Local prosecuting officials concede that "great weight" is given to the victim's desires in serious felony cases, especially homicides. This could mean that if ... the facts and circumstances of a case do not clearly warrant prosecution for an unlawful homicide, the adamant victim could overcome the prosecutor's reluctance to charge. 
In addition to the substantive questions raised by the court's new approach to PTI, the Guidelines also add another layer of motions, hearings, and appeals to the criminal justice system. Each decision, such as whether the crime was one of those within the categories of ordinarily excluded offenses, whether a previous offense was "serious," or whether the defendant possesses the requisite rehabilitative potential, may be the subject of litigation. Although defendants face a heavy burden in challenging prosecutors, the Guidelines allow defense counsel to delay proceedings by contesting and appealing a variety of heretofore unreviewable issues. As the Attorney General warned following the Leonardis decision, "PTI will become another time-consuming facet of an already lengthy process instead of serving its intended purpose of expediting dispositions and permitting a reallocation of resources." 48

\section{Drug Treatment}

In State v. Alston ${ }^{49}$ and State v. Sayko, ${ }^{50}$ the court affirmed the propriety of admitting defendants found guilty of drug possession into a statutorily created drug treatment program. In so doing, the court attempted to clarify the factors to be considered by the trial judge in admissions decisions.

Section 27 of the New Jersey Controlled Dangerous Substances Act ${ }^{51}$ provides an opportunity for first offenders charged with, or found guilty of, possession of or being under the influence of certain "controlled dangerous substances" to receive treatment and to avoid the stigma of a criminal conviction. The trial court may suspend proceedings and place such defendants under supervisory treatment for a period not exceeding three years. ${ }^{52}$ Upon completion of the treatment program, the court

Hall, The Role of the Victim in the Prosecution and Disposition of a Criminal Case, 28 Vand. L. Rev. 931, 948 (1975). See also Nimmer, supra note 13, at 13 . For other criteria which prosecutors may feel are relevant to the decisionmaking process and which appear to be outside the standard approved by the court, see National District Atrorneys Assoc.: Screening of Chiminal Cases 2 (undated); ProsecuTION, supra note 40 , at $92-98$.

48. Petition of State for Clarification and Application for Stay at 8, State v. Leonardis, 71 N.J. 85, 363 A.2d 321 (1976). See also Gagnon v. Scarpelli, 411 U.S. 778, 787-88 (1973). An appreciation of the amount of litigation which the court's policy might engender can be gained from estimates that there will be 13,000 applicants for PTI each year when the program is available statewide, and that one half of those applicants $(6,500)$ will not be accepted for admission. Paul, supra note 3, at 878 . But see State v. White, 145 N.J. Super. 257, 367 A.2d 469 (Law Div. 1976) (evidence may not be presented to the court in order to substantiate murder defendant's claim that program director and prosecutor acted arbitrarily in denying PTI admission).

49. 71 N.J. 1, 6, 362 A.2d 545, 548 (1976).

50. 71 N.J. 8, 11-12, 362 A.2d 549, 551 (1976).

51. N.J. Stat. ANN. $\$ 24: 21$ (Supp. 1976).

52. N.J. Stat. AnN. $\$ 24: 21-27$ (Supp. 1976). 
may dismiss further proceedings against the defendant. ${ }^{53}$ Subsection (c), however, provides:

$[\mathrm{P}]$ roceedings under this section shall not be available to any defendant unless the court in its discretion concludes that:

(1) The defendant's continued presence in the community, or in a civil treatment center or program, will not pose a danger to the community; or

(2) That the terms and conditions of supervisory treatment will be adequate to protect the public and will ben-fit the defendant by serving to correct any dependence on or use of controlled substances which he may manifest. ${ }^{54}$

In Alston, a former police officer, found guilty of possession of heroin, was admitted to a section 27 program over the prosecutor's objection that Alston was ineligible because he was not found to be a drug user. The prosecutor also contended that Alston was a danger to the community and thus ineligible under subsection (c), because successful completion of a section 27 treatment program would permit him to resume his position as a police officer. ${ }^{55}$ In Sayko, the defendant, who pleaded guilty to possession of L.S.D., amphetamines, and marijuana, ${ }^{56}$ was denied admission to a treatment program because he made no effort to interfere with the drug involvement of his younger, less educated sister, with whom he shared an apartment. ${ }^{57}$

The court determined that admission into a drug treatment program was the proper disposition in both cases. ${ }^{58}$ Based upon statutory language which specifically included drug possession offenses, ${ }^{50}$ the court rejected arguments that treatment could only benefit drug users. The court found that, although the primary objective of the program is treatment of users, "[p]rospective users, early stage users or experimenters" may also benefit from counseling and monitoring. ${ }^{.0}$ In addition, the court noted that such defendants were "no less entitled" to the opportunity to avoid the stigma of a criminal conviction than "acknowledged users." " 1

53. In the event of a guilty verdict, a judgment of conviction would not be entered. N.J. Stat. ANN. 24:21-27(b) (Supp. 1976).

54. N.J. Stat. ANN. $\$ 24: 21-27$ (c) (Supp. 1976).

55. 71 N.J. at 3-6, $362 \mathrm{~A} .2 \mathrm{~d}$ at 545-48. Alston was acquitted of possession of heroin with intent to distribute. Id. at 3, 362 A.2d at 545-6.

56. Charges of possession with intent to distribute were dismissed with the consent of the state. Id. at 10, 362 A.2d at 550 .

57. Transcript of sentence at 3-5, 10, 11, State v. Sayko, No. 711-JS-1972 (Law Div. Union County, Dec. 6, 1973).

58. State v. Sayko, 71 N.J. at 7, 362 A.2d at 548; State v. Alston, 71 N.J. at 13,362 A.2d at 552 .

59. N.J. Stat. ANn. $\$ 24: 21-27$ (a) (Supp. 1976) lists offenses which deal with obtaining, possessing, and being under the influence of certain amounts of specific controlled dangerous substances.

60. 71 N.J. at 5-6, $362 \mathrm{~A} .2 \mathrm{~d}$ at 547 .

61. Id. at $6,362 \mathrm{~A} .2 \mathrm{~d}$ at 548 . 
The court provided guidance in the use of subsection (c) in two important respects. First, the court construed "a danger to the community" to refer only to the threat posed by the "defendant's conduct while a participant in the program." ${ }^{62}$ Thus, the fact that Alston might have the opportunity to regain his position as a policeman after completion of the program was considered irrelevant to his admission to a section 27 program. ${ }^{63}$ Second, resolving a conflict in lower court decisions, ${ }^{64}$ the court declared that the trial court had discretion to exclude defendants who satisfied the criteria set forth in subsection (c) ${ }^{65}$ While courts are not confined by subsection (c), the court in Sayko determined that trial courts must use the "whole person concept" to determine whether a defendant should be admitted to a treatment program. ${ }^{66}$ Noting that Sayko was a college graduate, had just secured full-time employment, was planning to get married, and was a first offender, the court, applying the "whole person concept," affirmed the appellate division's holding that the defendant's motion for admission to a section 27 program should have been granted. ${ }^{67}$ The court found that, with regard to Sayko's conduct vis-a-vis his sister, the trial court improperly focused on the crime committed rather than on the general character of the defendant. ${ }^{68}$ In stressing the importance of adding personal factors to the evaluation, however, the court may have prevented trial courts from giving sufficient consideration to the seriousness of the crime the defendant committed.

Alston and Sayko expand the scope of section 27 by removing all doubt as to its applicability in cases which do not involve proven drug use. The court could have interpreted the word "supervisory treatment" and the reference to correction of drug dependence in subsec-

62. Id. at 7, $362 \mathrm{~A} .2 \mathrm{~d}$ at 548 .

63. The prosecution argued that a policeman with a background of possession of heroin may be a danger to the community. Id.

64. Compare State v. Bush, I34 N.J. Super. 346, 340 A.2d 697 (Law Div. 1975) (any defendant who comes within $\oint 27(\mathrm{c})$ must be admitted), and State v. Sayko, No. A-1282-73 (N.J. Super. Ct. App. Div. 1975) (trial court criticized for not making any findings on the basis of $\$ 27(\mathrm{c})$ criteria) with State v. Johnson, 137 N.J. Super. 27, 347 A.2d 543 (App. Div, 1975) (trial court's authority is not "circumscribed and defined solely" by $\$ 27(\mathrm{c}))$.

65. 71 N.J. at 13,545 A.2d at 552 .

66. Id. The whole person concept was described in State v. Green, 62 N.J. $547,566-67,303$ A.2d $312,322-23$ (1973) as a composite picture of the character of the defendant.

67. 71 N.J. at 13,362 A.2d at 552.

68. The trial judge, however, had simply exercised his discretion in accordance with the standard proposed in State v. Johnson, 137 N.J. Super. 27, 31, 347 A.2d 543, 545 (App. Div. 1975). There the appellate division determined that in sentencing decisions, the court should consider the further criminal implications of the defendant's conduct and the circumstances surrounding the criminal event. Id.

The supreme court's emphasis on considering the offender as opposed to the offense is consistent with the policy established in PTI admissions decisions. See notes 1-48 and accompanying text supra. 
tion (c) to mean that treatment was available only to those who use drugs. By refusing to confine section 27 to drug users, the court reaffirmed the state policy of more lenient treatment for minor first drug offenses. ${ }^{60}$

\section{Restitution as a Condition of Probation}

In State ex rel. D. G. $W .^{70}$ and State v. Harris, ${ }^{71}$ the court approved the imposition of restitution as a condition of probation for juvenile and adult offenders. In addition, the court established procedures necessary to afford due process in sentencing where restitution is imposed.

D.G.W., a juvenile, pleaded guilty to charges of breaking and entering, theft, and destruction of property, along with three other youths. The juvenile and domestic relations court placed D.G.W. on probation for one year and required that he make restitution to a victim of the offense as a condition of his probation. The probation department, acting at the judge's order, determined that the youths had caused $\$ 626$ worth of damage at one of the schools they had vandalized. D.G.W. was ordered by the probation department to pay one-fourth of that amount, $\$ 156.50 .^{72}$ The defendant contested the authority of the court to impose such a condition. ${ }^{73}$

The supreme court held that the trial court possessed the authority to impose restitution under the statutes authorizing reparation or restitution as a condition of probation ${ }^{74}$ and the statutes allowing probation for juveniles "upon such written conditions as the court deems will aid rehabilitation . . .." ${ }^{75}$ The court found that restitution was a rehabilitative measure and therefore was a valid disposition in juvenile matters. ${ }^{76}$

In finding the existence of statutory authority for the imposition of restitution, the court distinguished State v. Mulvaney ${ }^{77}$ and State ex rel. M.L. ${ }^{78}$ in which the court had required statutory authorization independent of the general probation statute in order to validate the imposition of fines and costs as a condition of probation. In Mul-

69. See note 13 supra.

70. 70 N.J. 488,361 A.2d 513 (1976).

71. 70 N.J. 586,362 A.2d 32 (1976).

72. 70 N.J. at 492,361 A.2d at 515 .

73. Id. at $493,361 \mathrm{~A} .2 \mathrm{~d}$ at 515 .

74. Id. at 501, 361 A.2d at 520; see N.J. Stat. AnN. 2A:168-1 (1971).

75. N.J. Stat. AnN. $\$ 2 A: 4-61$ (Supp. 1976); N.J. Ct. R. 5:9-9.

76. $70 \mathrm{~N}$.J. at $500-01,361 \mathrm{~A} .2 \mathrm{~d}$ at $519-20$.

77. 61 N.J. 202,293 A.2d 668 (1972) (per curiam).

78. 64 N.J. 438, 317 A.2d 65 (1974). See also People v. Grago, 24 Misc. 2d 739, 740, 204 N.Y.S.2d 774, 776 (Oneida County Ct. 1960); S. Rubin, Law of Criminal Conrection 296 (ed. 1973) (restitution is not an authorized sentence unless made so by statute). 
vaney, the court had determined that certain court-imposed costs were improper because contrary to specific provisions of the statute regulating award of court costs. ${ }^{79}$ The restitution imposed in D.G.W., however, did not conflict with any express statutory provision. In $M . L .$, the court had found that the imposition of a fine on a juvenile was beyond its statutory authority. ${ }^{80}$ In D.G.W., the court distinguished M.L. by declaring that payment of a fine is punitive, whereas payment of restitution is rehabilitative. ${ }^{81}$

In State v. Harris, the court upheld the use of restitution as a condition of probation for adult offenders. ${ }^{82}$ Harris was convicted of fraudulently obtaining money from the Bergen County Welfare Board by concealing employment earnings. The trial judge imposed a suspended sentence and three years of probation, with a condition of restitution of $\$ 1,012{ }^{83}$ The court determined that, since the goal of probation is rehabilitation, and the payment of restitution is rehabilitative, the general probation statute authorized the imposition of restitution on an adult offender. ${ }^{84}$

In D.G.W. and Harris, the defendants attacked the procedures used by the trial judge in fixing the amount and terms of restitution. In response, the court determined that due process is satisfied by providing a summary hearing. The court's findings need only be supported by some factual basis, not a preponderance of the evidence. ${ }^{85}$ The supreme court then outlined the procedures to be followed in imposing restitution. First, the probation department must conduct an investigation into the extent of damages caused by the defendant and defendant's ability to pay. The department must then prepare a written report specifying the method used to determine the losses incurred. The report should be made available to the defendant prior to sentencing. At the sentencing hearing, the defendant may dispute the contents of the report and present evidence in his own behalf. Except in extraordinary circumstances, the defendant need not be allowed to cross-examine the sources upon which the probation department relied. The judge should then determine the proper valuation method, the amount of damage for which

79. 61 N.J. at $204-05,293$ A.2d at 669-70.

80. $64 \mathrm{~N}$.J. at $444,317 \mathrm{~A} .2 \mathrm{~d}$ at 68 .

81. See State ex rel. D.G.W., 70 N.J. at $495,497-98,362$ A.2d at 516, 518.

82. 70 N.J. at $591,362 \mathrm{~A} .2 \mathrm{~d}$ at 34 .

83. The jury finding of guilt was not determinative of the amount of money involved. The amount of restitution was determined by the judge based on evidence presented at trial and information in the presentence report. See id. at 590-91, 362 A.2d at $33-34$.

84. Id. at $592,362 \mathrm{~A} .2 \mathrm{~d}$ at 35 .

85. See State ex rel. D.G.W., 70 N.J. at 502-07, 361 A.2d at 521-23; State v. Harris, 70 N.J. at 594, 597-99, 362 A.2d at 36, 37-39. While a defendant may challenge the allocation of damages among multiple defendants, there is a presumption of proportionate liability against each defendant. 70 N.J. at 508, 361 A.2d at 524 . 
the defendant will be held responsible, how much the defendant is able to pay, and the terms of payment. The judge must also state the reasons for his decision to impose restitution.

In D.G.W., the court remanded with directions to reestablish the amount of restitution because the probation department, not the trial court, had determined the terms of payment, and there had been no hearing as to the defendant's proportional liability or his ability to pay. ${ }^{86}$ In Harris, noting that the trial court had not conducted the requisite investigation and had not sufficiently considered the ability of the defendant to pay, the court vacated the restitution condition as being excessive. ${ }^{87}$ In view of the defendant's financial situation as a "welfare mother" struggling to support five children, the court found that restitution served no legitimate penal purpose. ${ }^{88}$

Harris may be read to prohibit imposition of restitution on defendants who are welfare recipients. ${ }^{89}$ This might work to the disadvantage of such defendants. Since some form of punishment will often be considered necessary if the offense and defendant's personal record are less favorable than in Harris, imprisonment may be imposed on a welfare defendant whereas restitution would have been acceptable for an economically independent defendant. It is unclear how trial judges will determine punishment in this situation. ${ }^{90}$ Perhaps judges will attempt to fashion more creative punishments, such as requiring some type of community service, which may in fact have greater rehabilitative value. ${ }^{91}$

While Harris may limit the application of restitution, both Harris and D.G.W. continue the supreme court's expansion of due process rights in sentencing. ${ }^{92}$ Although the New Jersey Supreme Court has gone farther than the federal courts, ${ }^{93}$ it may not have gone far enough in establishing the procedure for deciding the quantum of restitution and the standard for determining the effect of the sentence on the defendant.

86. Id. at 503-04, 507-09, 361 A.2d at 521-22, 523-24.

87. 70 N.J. at 596-97, 362 A.2d at 37. For further discussion of Harris and review of allegedly excessive sentences, see generally 30 Rutgers L. Rev. 657 (1977).

88. Id. at 596-97, $362 \mathrm{~A} .2 \mathrm{~d}$ at 37 .

89. The application of Harris could be limited to situations where welfare recipients would have to make restitution to the same agency that must continue to provide the recipient a subsistence allowance.

90. The trial court in Harris was obviously troubled by this dilemma. See Transcript of Sentence at 10-12, State v. Harris, No. S-295-73 (Law Div. Bergen County, July 26, 1973).

91. See R. Goldfari \& L. Singer, After Conviction 141 (1973). The court seems to favor such sentences. See State ex rel. D.G.W., 70 N.J. at 500 n.3, 361 A.2d at $519-20$ n.3.

92. See State v. Kunz, 55 N.J. 128, 259 A.2d 895 (1969).

93. For example, no statement of reasons is required in federal courts following sentencing. See, e.g., Dorszynski v. United States, 418 U.S. 424 (1974); United States v. Velazquez, 482 F.2d 139, 142 (2d Cir. 1973). 
The court's newly adopted procedures closely parallel procedures required in parole and probation revocation hearings, ${ }^{94}$ which merely determine whether a violation of a previously established condition has occurred. ${ }^{95}$ In proceedings to establish restitution, however, a new liability is being determined. Since the defendant has been convicted in a proceeding in which he has had all of the procedural rights of a criminal trial, it might be thought that assessment of liability should be relatively simple. There are, however, many complex questions involved in that determination. For example, the actual amount of damages is not necessarily proven at trial. In Harris, the finding of guilt required no establishment of the amount illegally taken by the defendant; in fact, the records and testimony were confused on that point. ${ }^{96}$ The amount of damage actually caused by any act is open to dispute. ${ }^{97}$.

Furthermore, it is not clear whether the New Jersey courts will be able to impose restitution for damages resulting from acts other than the precise ones of which the defendant was convicted. ${ }^{98}$ If the courts

94. See, e.g., Morrissey v. Brewer, 408 U.S. 471 (1972); State v. Johnson, 133 N.J. Super. 457, 337 A.2d 387 (App. Div. 1975).

95. See, e.g., N.J. STAt. ANN. \$ 2A:167-9, -10, 2A:168-4 (1971); Lathrop v. Lathrop, 50 N.J. Super. 525, 534-35, 142 A.2d 920, 925 (App. Div. 1958).

96. Brief for Defendant-Appellant at 2-16, State v. Harris, No. A-99-73 (App. Div. Dec. 24, 1974). At trial the judge excluded as irrelevant evidence that the defendant was not receiving support payments. Brief at 22 . Such evidence, however, would have been relevant to the issue of damages.

97. For example, in People v. Miller, 256 Cal. App. 2d 348, 64 Cal. Rptr. 20 (1967), the defendant defrauded the victim of $\$ 821$ by failing to do promised construction work but was required to pay $\$ 8,600$ as a condition of probation. The balance was the court's determination of the loss that resulted from the criminal act.

98. Many states and the federal courts limit restitution payments to the crime for which the defendant was convicted. See, e.g., United States v. Taylor, 305 F.2d 183, 187 (4th Cir. 1962); People v. Funk, 117 Misc. 778, 193 N.Y.S. 302 (Erie County Ct. 1921). Other states, however, permit payments to all parties aggrieved by a "course of criminal conduct." People v. Gallagher, 55 Mich. App. 613, 618, 223 N.W.2d 92, 95 (1974). The New Jersey statute could lead to either result. It authorizes "restitution to the aggrieved parties for the damage or loss caused by his offense ...." N.J. STAT. ANN. \$2A:168-2 (1971). The proposed New Jersey Penal Code does not deviate significantly. It provides for "restitution of the fruits of his offense in an amount he can afford to pay, for the loss or damage caused thereby...." I New Jersey Criminal Law Revision Commission, The New Jersey Penal Code $\$ 2$ C:45-1 (1971) (proposed).

Dicta in both D.G.W. and Harris may also be read to support either construction of the New Jersey statute. For example, the court's repeated emphasis that sentences should be tailored to the offender and not the offense may imply that a proper restitution order should include all ill-gotten gains or damage done by the defendant. See, e.g., State ex rel. D.G.W., 70 N.J. at 508, 361 A.2d at 524; State v. Harris, 70 N.J. at 594,362 A.2d at 36 . Similarly, the limited standard of proof required and the court's willingness to allow restitution payments where the amount was not properly specified in the indictment indicate that the conviction does not limit the scope of the restitution payments ordered. State v. Harris, 70 N.J. at 597-98, 362 A.2d at 37-38. On the other hand, there is language to support the adoption of the federal approach. For example, "[ $t]$ he restitution or reparation required may not go beyond 
are not so confined, the sentencing judge will have to consider additional factual issues. The limited scope of the summary sentencing procedure may, however, expose the criminal defendant to what is essentially a civil liability with less procedural protection than he would have in a civil trial. ${ }^{99}$ The defendant has limited ability to contest the probation department's determination of valuation. Such civil defenses as proximate cause and comparative or contributory negligence are unavailable to the defendant. Finally, the judge's findings may be supported by less than a preponderance of the evidence. Although conditions of probation cannot be imposed without the consent of the defendant, ${ }^{100}$ that consent is given under threat of a prison sentence. Consequently, it is no substitute for adequate procedural safeguards.

The due process requirements adopted by the court are also inadequate for determining whether restitution will in fact serve a rehabilitative purpose. While many experts agree that restitution will often be beneficial to the defendant, they do not necessarily agree that restitution is a desirable disposition for all defendants. ${ }^{101}$ Therefore, the

the actual loss or damage as established in the prosecution and must be directly related to the crime." State $e x$ rel. D.G.W., 70 N.J. at 500 n.3, 361 A.2d at 519 n.3, quoting S. Rubin, The Law of Chiminal Correction, 200-01 (ed. 1963). Moreover, in D.G.W. the court indicated that as part of the required procedure prior to sentencing, the probation department should "conduct an investigation of the incident[s] contained in the complaint ..."7 70 N.J. at 503, 361 A.2d at 521. This seems to limit the scope of restitution.

99. The New Jersey statute authorizes both restitution and reparation. N.J. STAT. ANN. $\$ 2 A: 168-2$ (1971). "Restitution normally consists of reimbursement of that sum of money which the defendant appropriated in the commission of his criminal act .... Reparation is generally considered to be synonymous with tort damages ...." Best \& Birzon, Conditions of Probation: An Analysis, 51 Geo. L.J. 809, 826 (1963).

100. N.J. Cr. R. 3:21-7 requires the defendant to sign a receipt upon receiving a copy of the conditions of probation. If he refuses to sign, he is resentenced.

101. The issue of whether restitution in general and in these cases in particular is rehabilitative was not litigated in either case. Hence, the court's conclusions were based on its own independent investigation. The court's conclusion that restitution is rehabilitative was based on dicta from cases in other jurisdictions and quotations from several books on penology. But the court's own authorities do not necessarily support the view that restitution is always rehabilitative. For example, one of the quoted authorities cited in both D.G.W. and Harris in support of restitution as a rehabilitative tool has also stated: "To be sure, treatment considerations may indicate that restitution should not be ordered. It is no magic formula. The backgrounds and needs of the individual case should determine whether or not the stipulation is to be laid down." D. Dressler, Phactice and Theony of Probation and Parole 241 (2d ed. 1969). Another commentator has reported: "A probation and parole agent in the Wisconsin State Department of Public Welfare stated that he thought restitution orders frequently interfered with the rehabilitation of probationers. He said that probation was in danger of becoming a form of collection for victims rather than a period of rehabilitation for probationers." R. Dawson, Sentencing: The Decision as to Type, Lencth, and Conditions of Sentencing $105 \mathrm{n} .15$ (1969). See also RuBIN, supra note 78, at 231-32 \& n.130. It appears that in order for restitution to have the desired effect, it must be considered as part of a total treatment program 
court should have included a requirement that the presentence report attempt to evaluate the psychological impact of the sentence upon the defendant. $^{102}$

\section{Conclusion}

In considering the disposition of criminal defendants, the New Jersey Supreme Court has given priority to the goal of rehabilitation. The court has sought to establish procedures which would insure that each defendant receives treatment tailored to his individual needs.

The desire for the criminal justice system to have a positive impact on those with whom it deals has a long history in this country. ${ }^{103}$ Disillusionment with the ability of prisons to achieve significant rehabilitative results has been growing, however. ${ }^{104}$ It remains to be seen whether the use of alternative dispositions which the New Jersey Supreme Court appears to be encouraging will be able to achieve the results it was once sincerely believed that prisons could achieve. It may be that the court will continue to find rehabilitation an elusive goal. Furthermore, the standards the court has used in discussing rehabilitation may prejudice other objectives, such as equal treatment of offenders and minimization of administrative arbitrariness. For example, de-

and imposed only where it will serve the psychological needs of the particular defendant. Courts have long recognized that "[t]here can be no real reformation of a wrongdoer, unless there is at least a willingness on his part to right the wrong committed." People v. Lippner, 219 Cal. 395, 399, 26 P.2d 457, 458 (1933).

It is doubtful whether court-imposed restitution can be conducted in the voluntary atmosphere necessary for rehabilitation. The initial decision to accept probation and its concomitant conditions is made with a prison sentence as the alternative. Moreover, the coercive nature of probation increases after the terms have been established. A defendant who feels that the making of restitution payments is wrong must consider the fact that, by refusing to continue making such payments, he will subject himself not only to the sentence he originally escaped but also to treatment as if he had committed an additional crime, to wit, probation violation. The defendant knows that although probation violation is not really a crime, it is treated as such by the courts. A court is likely to impose a higher sentence when probation is violated than it would have imposed before the imposition of probation. See, e.g., Remer v. Ragan, 104 F.2d 704 (9th Cir.), cert. denied, 308 U.S. 553 (1939); In re White, 18 N.J. 449, 114 A.2d 261 (1955); State v. Driesse, 95 N.J. Super. 491, 494, 231 A.2d 835, 836 (App. Div. 1967). Furthermore, probation violation is part of a person's record which is considered in sentencing for subsequent crimes. See Dawson, supra, at 82 .

102. As indicated in note 23 supra and accompanying text, the courts may not be able to make such a determination. This calls into question the legitimacy of imposing restitution if the court feels that it can only be justified as a rehabilitative tool.

103. See D. Rothman, The Discoveny of The Asylum 79-108 (1971). The system of indeterminate sentencing used throughout the country is an outgrowth of the "rehabilitative ideal." See H. Packer, The Limits of the Criminal Sanction 53-58 (1968); Allen, Criminal Justice, Legal Values and the Rehabilitative Ideal, 50 J. Crum. L. Criminology \& Police Sci. 226, 226-27 (1959).

104. See, e.g., O'Leary, Gottfredson, \& Gelman, Contemporary Sentencing Proposals, 2 Crim. L. Bull. 555 (1975); State Correction Chief Asks End To Indeterminate Tertas in Prison, N.Y. Times, Dec. 14, 1976, at 40, col. 1. See also note 13 supra. 
fendants accused of committing the same crime are to be treated differently based on factors unrelated to their offense. ${ }^{105}$ The vagueness of such criteria and the fact that even professionals would differ on particular judgments will make statewide uniformity and predictability in applying the court's standards difficult to achieve. ${ }^{108}$

Charles Shafer

105. The New Jersey Supreme Court has implicitly approved criteria based on whether the defendant belongs to a class of people likely to commit crimes. In Leonardis, for instance, the court cited defendant Leonardis' employment and unblemished record and defendant Rose's full-time student status as "pertinent factors" relating to their "rehabilitative potential." $71 \mathrm{~N} . J$. at $111-12,363 \mathrm{A.2d}$ at 335 . The same kinds of factors led the court in Sayko to conclude that the defendant should have been admitted to a section 27 program. See text accompanying note 67 supra. Use of these criteria is acknowledged as a "creaming" process in New Jersey PTI programs. Zaloom, supra note 5, at 191. "This leads to a situation where persons are punished for what it is believed they will do, rather than for what they have done." O'Leary, Gottfredson, \& Gelman, supra note 104, at 565 (1975). Judge Frankel recognized the middle-class bias of "individualized justice" as being at war with the concept of equal treatment before the law. M. Franker, Criminal SenTENCES 10-11 (1972).

106. See Coffee, supra note 23 , at 1373. This is the same danger presented by the application of the rehabilitative ideal to other phases of the criminal justice system: "At every level-from prosecutor to parole-board members-the concept of individualization has been used to justify secret procedures, unreviewable decision making, and an unwillingness to formulate anything other than the most general rules or policy." American Friends Service Committee, Strugcle for Justice 40 (1971). 